\title{
Environmental impact of alum shale mining and oil and uranium production in Kvarntorp, Sweden, based on historical archives and environmental monitoring data
}

\author{
Kristina Åhlgren*, Mattias Bäckström
}

Man Technology Environment Research Centre, Örebro University, SE-701 82 Örebro, Sweden

Received 1 December 2020, accepted 10 November 2021, available online 10 December 2021

\begin{abstract}
Oil production (1942-1966) and uranium extraction (1953-1961) from the Alum Shale Formation in Kvarntorp, Sweden has had a great environmental impact on the area. Other industrial activities have also contributed to pollution. This study combines archive research with monitoring data and new sampling in order to assess the extent of the impact. During the production period, process water containing oil, phenols, sulfur compounds and high concentrations of iron reached the stream resulting in low water quality downstream. Also the landscape was reshaped, resulting in water filled pit lakes and a 100-meter-high shale waste deposit. Today, past alum shale activities still have an impact on the environment. Sulfate concentrations in the pit lakes are significantly higher than background values and downstream water also shows higher concentrations of elements such as nickel and uranium. The waste deposit still has a hot interior and an important question is the cooling rate and possible future leaching scenarios. Remaining hydrocarbons show today only a local impact while trace elements are transported downstream and affect a larger area.
\end{abstract}

Keywords: alum shale, black shale, uranium, Kvarntorp.

\section{Introduction}

Shales as unconventional energy resources are a debated topic and, in some places, not yet exploited resources are investigated alongside possible impacts on the environment [1-3] and greenhouse gas emissions [4]. At other places shale oil production has already left scars in the landscape [5-7]. The largest shale waste semi-coke landfill in the world, situated in Kohtla-Järve, Estonia, was opened in the 1930s and is a source of contamination as landfill gases are

\footnotetext{
* Corresponding author: e-mail kristina.ahlgren@oru.se

(C) 2021 Authors. This is an Open Access article distributed under the terms and conditions of the Creative Commons Attribution-NonCommercial 4.0 International License (http://creativecommons.org/licenses/by-nc/4.0/).
} 
emitted and also leachates containing phenols have reached the Kohtla River [8]. Studies indicate an increased leachability of polycyclic hydrocarbons (PAHs) with time [9]. Some shales are also of interest due to potential metal recovery. Black shale deposits are estimated to be about the 14th most important uranium resource from an economical perspective [10] and there is ongoing research about recovery methods [11].

Alum shale is a black shale enriched in both organic matter (kerogen) and several metals such as molybdenum, nickel, uranium and vanadium. In addition, it contains pyrite, which may lead to acid rock drainage and increased metal release $[12,13]$. The Alum Shale Formation got its name in the 17 th century when it was used for production of alum, $\mathrm{KAl}\left(\mathrm{SO}_{4}\right)_{2} \cdot 12 \mathrm{H}_{2} \mathrm{O}$ [14]. This shale can be found in several places in northern Europe. For example, in the Oslo area in Norway [15] attention has to be paid both during construction works (since the shale expands when in contact with water which can affect constructions) and to shale waste disposal [16] (since the water generates pollutant leachates), but also in Bornholm in Denmark [17] and in Estonia [18]. Alum shale can also be found in Sweden (see Fig. 1 [14]), where about 460000 tonnes of shale was mined and burned to produce alum in Degerhamn, Öland during the 18th-19th centuries [19]. Alum shale has been noted to have both a natural and an anthropogenic impact on the environment [20]. In Ranstad, the shale was mined for uranium during the 1960s and still 30 years later, elevated concentrations of nickel and uranium were found in the drainage water $[21,22]$.

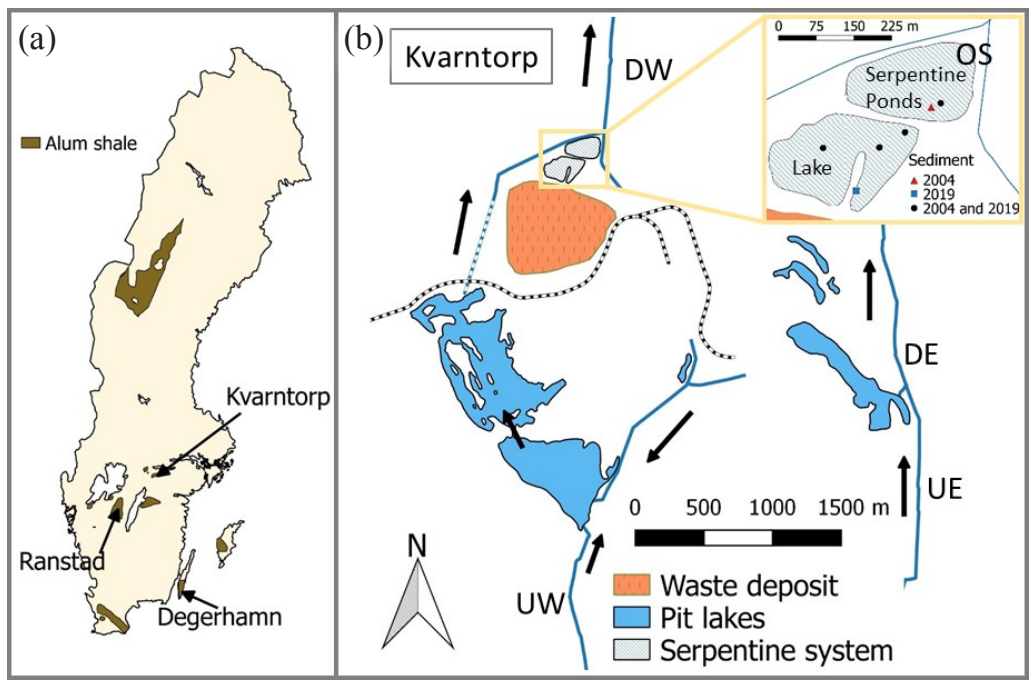

Fig. 1. (a) Map showing alum shale deposits in Sweden [14]; (b) Kvarntorp area with water sampling points (marked as $\mathrm{UW}=$ upstream west, $\mathrm{DW}=$ downstream west, $\mathrm{UE}=$ upstream east, $\mathrm{DE}=$ downstream east, $\mathrm{OS}=$ outlet Serpentine system). 
As the Swedish Navy suffered during World War II from lack of liquid fuel, attempts were made to find the best suited alum shale location for oil production in the country. For this purpose, Kvarntorp, Närke was chosen, however, this resulted in a reshaped landscape and significant environmental impact from exploitation of black shale, as well as from related industrial activities. The generated waste materials contained sulfide minerals, trace elements and organic compounds.

Globally, there is an increased interest in extracting oil, gas or metals from black shale formations. It is important to understand and gain experience from the long term environmental impact in Kvarntorp since it was one of the first full-scale industrial operations for oil and uranium production from black shale, which still, more than 50 years after closure, show environmental impact.

\section{Geological conditions and description of the area}

In Kvarntorp the crystalline basement is followed by Lower Cambrian Mickwitzia sandstone, Lingulid sandstone, phosphorite and glauconite sandstone, Middle Cambrian shale, Upper Cambrian alum shale and then Ordovician limestone covered by till [23]. The upper shale unit has higher uranium concentrations $(245 \mathrm{mg} / \mathrm{kg} \mathrm{dw})$ while the oil content is higher below this unit [14]. All layers are not present in the entire area, since the bedrock is tilted towards the south making the sedimentary layer thinner northwards due to glacial erosion [24]. Figure 2 depicts the extension of the alum shale layers and a stratigraphic column.

The alum shale contains layers with stinkstones (bituminous bearing limestones) and kolm rich layers. Kolm consists of organic rich carbonaceous nodules, flat lenses enriched in uranium, normally around $3000 \mathrm{mg} / \mathrm{kg} \mathrm{dw}$ (up to $4000-5000 \mathrm{mg} / \mathrm{kg} \mathrm{dw}$ ) [24].

There are no natural lakes, but several waterfilled open pits. Two streams pass through the area: Frommestabäcken in the west and Frogestabäcken in the east (Fig. 1). The western stream passes through Söderhavet and Nordsjön, the two largest pit lakes, before passing the waste deposit where water from the deposit as well as clean industrial cooling water is also discharged to the stream. Before discharging into the stream, waters from the waste deposit and the industrial area pass through a serpentine pond system with a small lake and serpentine ponds designed during the 1940s in order to reduce pollution of the downstream recipient. Frogestabäcken, in the east, receives water from the eastern pit lakes.

Scarce documentation about environmental impact during the production time, and initially scarce environmental monitoring afterwards, leads to a knowledge gap causing problems for decision making concerning reclamation strategies. Archive material could help to identify possible point sources and 
potential contaminants, which together with current monitoring and sample campaigns could reveal possible sources of contamination in the area. This paper shows that historical archives are important sources of information regarding possible chemicals present, extent of the contamination (both amounts and spatial distribution) and artificial pathways for contamination transport. The aim of this study is to assess the past, long-term and ongoing environmental impact from a full-scale alum shale oil production site with the help of archive material, monitoring data, sampling and chemical analysis.

\section{Methods}

\subsection{Archive studies}

In order to elucidate the extent and variety of past activities, archive material from the oil shale company Svenska Skifferolje AB (SSAB) was studied. Maps and photos describe the extension of open pits, while management reports provide data about production. Technical reports as well as some environmental investigations are also available. Digitized historical photos are available at Kumla municipality digital photo archive. Occasionally, from the mid-1970s to around 2005, environmental investigations were performed by consultants commissioned by the county board, Kumla municipality and the Geological Survey of Sweden. The resulting reports, although not always easily accessible and not available in English, contain important information for the understanding of the processes in the area. Map data from Lantmäteriet (Swedish Land Survey) was used to create maps using the software QGIS Desktop 2.14.13.

\subsection{Monitoring program}

Water upstream and downstream the area (4 localities, $n=40-145)$ and water discharging from the Serpentine system $(n=137)$ was sampled in a monitoring programme run by Kumla municipality [25]. Parameters such as $\mathrm{pH}$, electrical conductivity, major components and trace elements have been analysed. Continuous water flow measurements at some of the sampling points (outlet of Lake Nordsjön and discharge water from the Serpentine system) make it possible to perform mass transport calculations.

\subsection{Sediment sampling}

To evaluate the restoration of the Serpentine system, five sediment cores were sampled in the system on two occasions, before the restoration in 2004 and again in 2019. The cores were sampled from ice (see Fig. 1b for sampling points) by driving plastic pipes into the sediments by using a hammer. In 2004 
the samples were digested in concentrated nitric acid using a closed microwave and analysed for trace elements using an Agilent 4500 inductively coupled plasma-mass spectrometer (ICP-MS). In 2019 the samples were sent to MS Analytical (Vancouver) for analysis. For major elements analysis, the samples were fused with borate flux in a muffle furnace before the resulting beads were dissolved in dilute mineral acid. For analysis of $\mathrm{Al}, \mathrm{Ca}, \mathrm{Fe}, \mathrm{K}, \mathrm{Mg}, \mathrm{Mn}, \mathrm{Na}$ and $\mathrm{P}$ the inductively coupled plasma-optical emission spectrometer (ICP-OES) was used. For analysis of trace elements (As, Cd, Co, Cu, Mo, Ni, Pb, U, V and REEs) the samples were digested in aqua regia or in a 4-acid mixture prior to analysis using ICP-MS. Total sulfur and carbon in the 2019 samples were quantified by a LECO carbon and sulfur analyzer. The differences in digestion methods will probably give slightly higher trace element concentrations in the 2019 samples (concentrated nitric acid compared to aqua regia).

\section{Industrial complex}

\subsection{Oil production}

Oil from alum shale was already being produced at Kinnekulle, Västergötland when Kvarntorp was chosen for new production due to sufficiently high organic content and thin overburden. The company SSAB was formed by the government in 1941 and the first oil was produced in 1942 [26]. However, proving economically inviable [27], the oil production in Kvarntorp was ceased in 1966. At that time a total of about 50 Mtonnes of shale was mined [14]. Figure 2 a represents a map of the mined areas and Figure 3 shows photos from the production period.

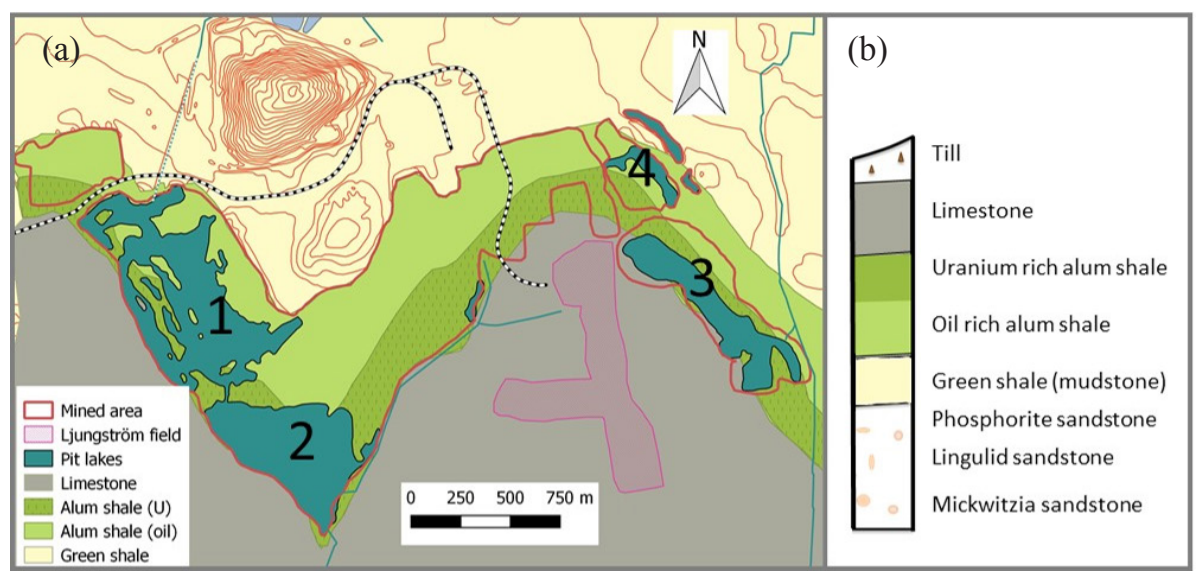

Fig. 2. (a) Map showing the mined area, Ljungström field and pit lakes ( $1=$ Nordsjön, 2 = Söderhavet, 3 = Norrtorpssjön, 4 = Surpölen); (b) stratigraphy of the sedimentary layers (not to scale). 


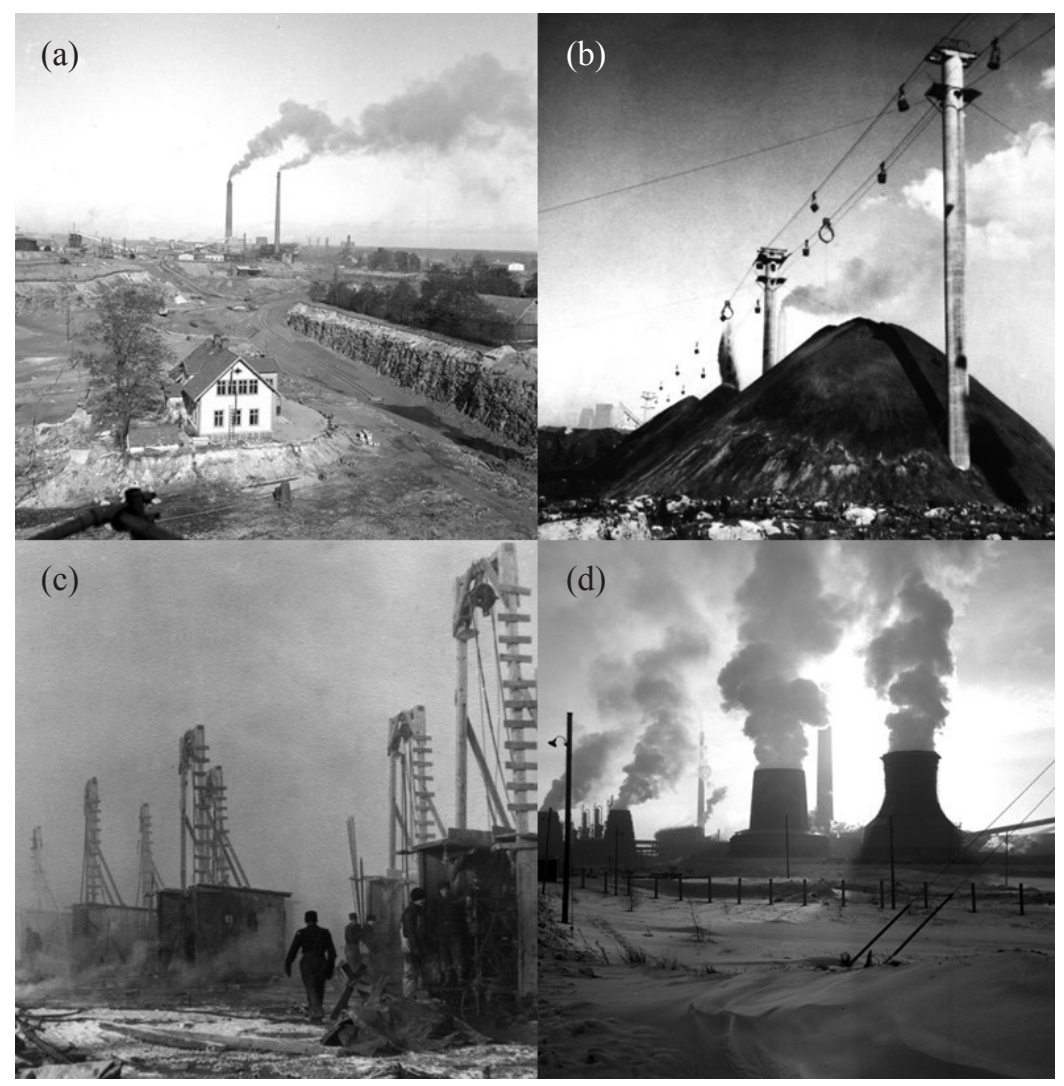

Fig. 3. Photos from Kumla municipality photo archive [28] showing the oil production in Kvarntorp during the 1940s-1950s: (a) former schoolhouse surrounded by a growing open pit (photographer unknown, SSAB); (b) growth of the Kvarntorp waste deposit (Kvarntorpshögen) (photographer unknown, SSAB); (c) derricks used for drilling (oil production in-situ with the Ljungström method) (photographer Harry Eriksson); (d) oil industry in Kvarntorp (photographer unknown, SSAB).

Shale was mined in open pits and transported with trucks to a primary crusher. After primary crushing, stinkstones were sorted by hand, and the shale was further crushed [29]. The crushed shale was then sieved in order to remove the finest fractions (fines, $<5-7 \mathrm{~mm}$ ) that caused sintering in the ovens [30]. The fines constituted about $20 \%$ of the mined shale [31, 32]. Originally, three different types of ovens were used for the dry distillation of the shale. In the so-called AB Industrimetoder (IM) ovens and the Hultman-Gustafsson oven the crushed shale with fractions above $30 \mathrm{~mm}$ was used and for the Bergh-Kvarntorp ovens the crushed shale needed to be 5-30 $\mathrm{mm}$ [26]. The Hultman-Gustafsson and IM ovens required gas for heating, which resulted in the shale waste consisting of semi-combusted shale (semi-coke), whereas the 
Bergh-Kvarntorp ovens used the produced semi-coke for its internal energy needs and generated a totally combusted shale residue with a distinct brick red colour called "rödfyr".

In addition to dry distillation oil was also recovered in situ at the Ljungström field (see Fig. 2) by a method developed by engineer Fredrik Ljungström. The ground was heated by electrodes inserted in boreholes, while other drilled holes served as collection points for the produced gas, which was then led to condensation plants. To produce $1 \mathrm{~L}$ crude oil, around $7.6 \mathrm{kWh}$ of electricity was needed [33], resulting in a poor Energy Return on Investment (EROI) as the energy content of oil only is around $10 \mathrm{kWh} / \mathrm{L}$. In 1945 , about $30 \%$ of the produced oil was extracted by the Ljungström method [26], which was in operation until November 1960 [27].

During the mid-1950s about 2.52 million tonnes of shale was processed annually in the ovens and 1 million tonnes during in situ production at the Ljungström field [34]. In the beginning of the 1960s some 3.4 million tonnes of shale was processed annually [35] and some $290 \mathrm{~m}^{3}$ of oil was produced every 24 hours, corresponding to an estimated oil yield of around $3.1 \%$. The production of fuel oil, petrol and sulfur in 1942-1964 is shown in Figure 4. Oil production facilities (object 4) with a refinery located between object 4 and object 5 can be seen in Figure 5. Final products were stored in big cisterns on a small hill called "Oljeberget" (the oil mountain) (object 5 in Fig. 5).

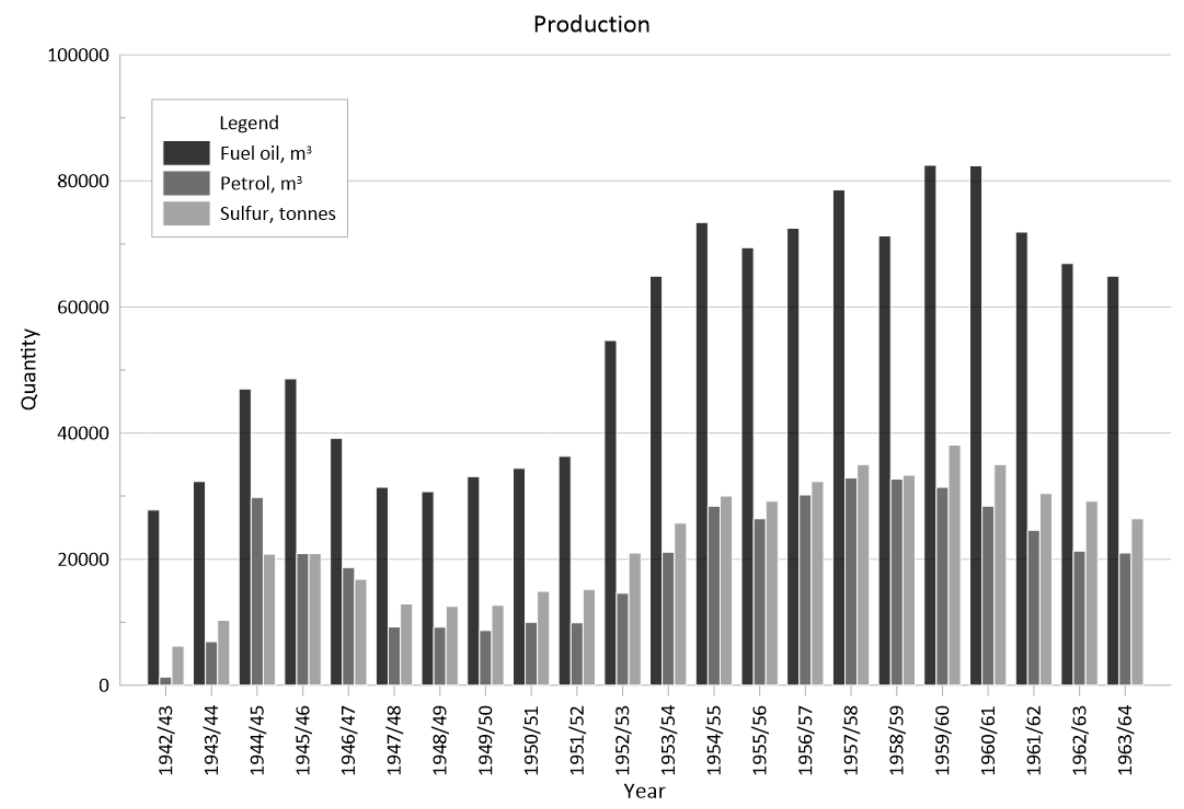

Fig. 4. Diagram showing the production of oil, petrol and sulfur in 1942-1960 (based on data from [36, 37, 38]). From 1942 to 1964 the total fuel oil production was $1.2 \mathrm{Mm}^{3}$, total petrol production $0.4 \mathrm{Mm}^{3}$ and sulfur 0.5 Mtonnes. 


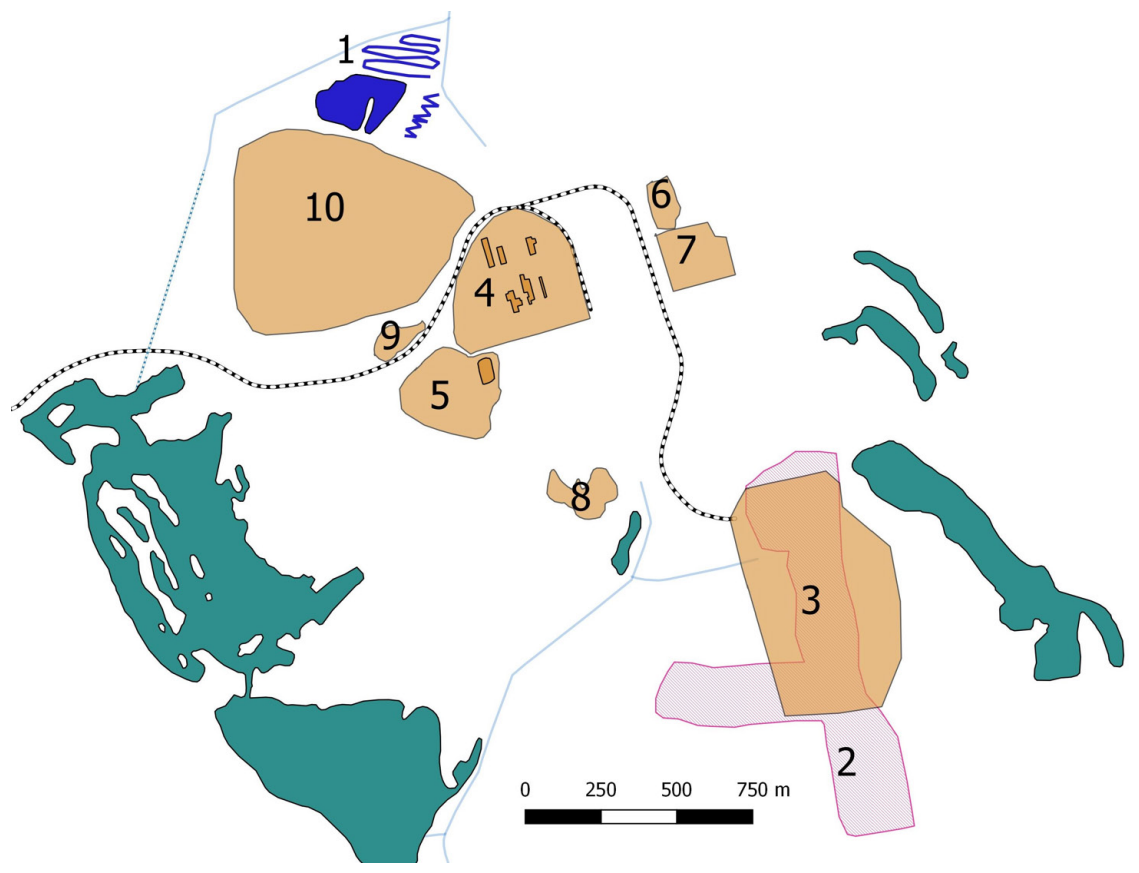

Fig. 5. Map of the industrial area showing: 1 - Serpentine system, 2 - Ljungström field, 3 - Fortum waste solutions (hazardous waste treatment plant, former SAKAB), 4 - SSAB with pyrolysis ovens, 5 - Oljeberget, 6 - Svarta havet, 7 - Supra, 8 - Leachate pond, 9 - Syrasjön, 10 - Kvarntorpshögen.

During production, flue gases caused problems with about 150 tonnes of sulfur emitted into the surroundings on a daily basis in the end of the 1950s [39]. In addition, more than $700 \mathrm{~m}^{3} / \mathrm{h}$ of process water was released into the stream Frommestabäcken during the first years of oil production. Most water came from the oven systems, extinction of semi-coke, the refinery or the Ljungström field, and contained oil, phenols, organic and inorganic sulfur compounds, ammonia, etc. Oil-separating basins were installed in 1945 and the water was then pumped up to the burning waste deposit where most of it evaporated. Towards the end of the summer of 1946 evaporation on the waste deposit decreased. However, there was still a significant removal of sulfur compounds, oil and phenols, while iron and aluminium reached the water course, resulting in the precipitation of oxy(hydr)oxides. During malfunctions the process water was redirected directly to the water course without passing the waste deposit. The recipient water showed low quality giving the fish a taste of oil. Liming initially showed promising results for removing iron, but concentrations remained elevated downstream. Water being filtered through the old layers of shale waste with soluble iron salts in addition to insufficient precipitation in the liming systems could be the reason for increased iron concentrations [40]. 
Open pits cover an area of about $2.6 \mathrm{~km}^{2}$. Most of this was later backfilled with processed shale, whereas some open pits were later used for disposing of municipal solid waste and industrial waste, for example. There are also some parts that were not backfilled and today remain as pit lakes. Shale residues that were not used for backfilling of the open pits were placed in a deposit (object 10, Fig. 5) on a site where the upper layer of the bedrock is composed of Middle Cambrian shale (a green mudstone). The deposit, called Kvarntorpshögen, grew from about $0.1 \mathrm{~km}^{2}$ in 1947 to $0.4 \mathrm{~km}^{2}$ in 1966 with a final volume of 40 million $\mathrm{m}^{3}$. In the beginning, the waste was transported to the deposit by trucks, but as the deposit grew, also cableways and later a conveyor belt were used. It is estimated that the deposit contains 23 Mtonnes of shale ash, 2 Mtonnes of semi-coke and 3 Mtonnes of fines [41]. Fines still contain organic matter and pyrite, which can lead to acid rock drainage. After the initial years of production, semi-coke was used as an energy source for some of the ovens. This is why it was expected to find less or no semi-coke in the waste dumped during the later stages of production. Semi-coke was therefore expected to be found mainly at the bottom and in the centre of the waste deposit. Both during oil production and afterwards fires were common in the deposit.

Temperature measurements of the surface have been carried out on several occasions. Temperature measurements at depth in drill holes have also been performed [41, 42]. In 2004 temperatures as high as $500-700{ }^{\circ} \mathrm{C}$ at some central parts at 10-15 m were recorded. A comparison between temperature profiles in 1983 and 2004 indicates that the depth where high temperatures are stabilized was greater in 2004 than in 1983. A possible interpretation is that the superficial material has been combusted and the material deeper down is burning now [41]. High temperatures have an impact on the hydrological cycle with higher evaporation and lower runoff generation. A crucial question has been the cooling rate of the deposit and whether leaching will increase, and to what extent, when the deposit cools down.

During the period of oil production, waste products such as sulfuric acid and oil residues were transferred to Syrasjön (object 9 in Fig. 5), where oil waste products were incinerated in the open. After the operation ceased, the lake was backfilled with demolition and concrete waste in 1985-1990.

\subsection{Ammonia production}

Also liquefied petroleum gas (LPG), sulfur and ammonia were produced from the shale. The ammonia plant was acquired by Svenska Salpeterverken (Swedish Saltpeter works) from SSAB in 1962 [43] and was later called Supra (object 7 in Fig. 5). Supra produced fertilizers from ammonia obtained from pyrolysis shale gas until the oil production ceased in 1966. Thereafter waste oil containing polychlorinated biphenyls (PCB) and chlorinated solvents were used as a hydrogen source, causing the process to stop more frequently. 
Water from the production with varying concentrations of soot was pumped to an area called Svarta havet ("the Black Sea") for sedimentation (object 6 in Fig. 5). When Supra was closed in 1982, Svarta havet was drained and covered [44].

\subsection{Uranium extraction (AB Atomenergi)}

In 1953 a uranium leaching plant was constructed in Kvarntorp. Uranium was leached from crushed shale with sulfuric acid and then precipitated as uranium phosphate or extracted by ion exchange. A concentrate was obtained containing a few dozen per cent of uranium that was transported to Stockholm for further treatment [45]). During 1953-1961 a total of 62 tonnes of uranium was produced in Kvarntorp, of which a smaller amount came from imported raw materials [46]. During the uranium extraction, residues from the leachates were transferred to a pond (object 8 in Fig. 5), which thus received shale residues, sulfuric acid residues and liquids rich in metals and uranium decay products [44].

\section{Environmental impact}

\subsection{Oljeberget, Supra, Svarta havet and Syrasjön}

Several sites at Kvarntorp are affected by the former industrial activities. At the site for Oljeberget (object 5, Fig. 5) aliphatic hydrocarbons $\left(>\mathrm{C}_{5}-\mathrm{C}_{16}\right)$, benzene, ethyl benzene and xylenes have been found in the soil (Table 1). A similar contamination profile has also been observed in the groundwater with free phase hydrocarbons in some parts of the area. At the Supra location where ammonia was produced (object 7, Fig. 5), the soil is for instance contaminated with PCB and aliphatic hydrocarbons (Table 1). Water downstream Svarta havet (object 6, Fig. 5) has been shown to contain high concentrations of $\mathrm{Cd}$, $\mathrm{Ni}$ and $\mathrm{Zn}$. It is believed that there are dioxins and PCB in the uppermost soil layers due to the use of chlorinated solvents and PCB containing waste oils in the process. Sampling and analysis of the material has failed to confirm this, as only aliphatic hydrocarbons and benzene have been found (Table 1). Leaching into the groundwater and further into the surface waters is apparent for the trace elements while the organic contaminants are immobilized within the solid waste.

At the location for Syrasjön (object 9, Fig. 5) elevated concentrations of aliphatic hydrocarbons, benzene, toluene, ethyl benzene, xylenes, carcinogenic polycyclic aromatic hydrocarbons (PAHs) and non-carcinogenic PAHs are found in the backfilled lake/pit (Table 1). Aliphatic hydrocarbons, benzene, toluene, ethyl benzene, xylenes and PAHs (both carcinogenic and non-carcinogenic) are also found in the groundwater, while trace element concentrations are not significantly elevated (Table 1). 


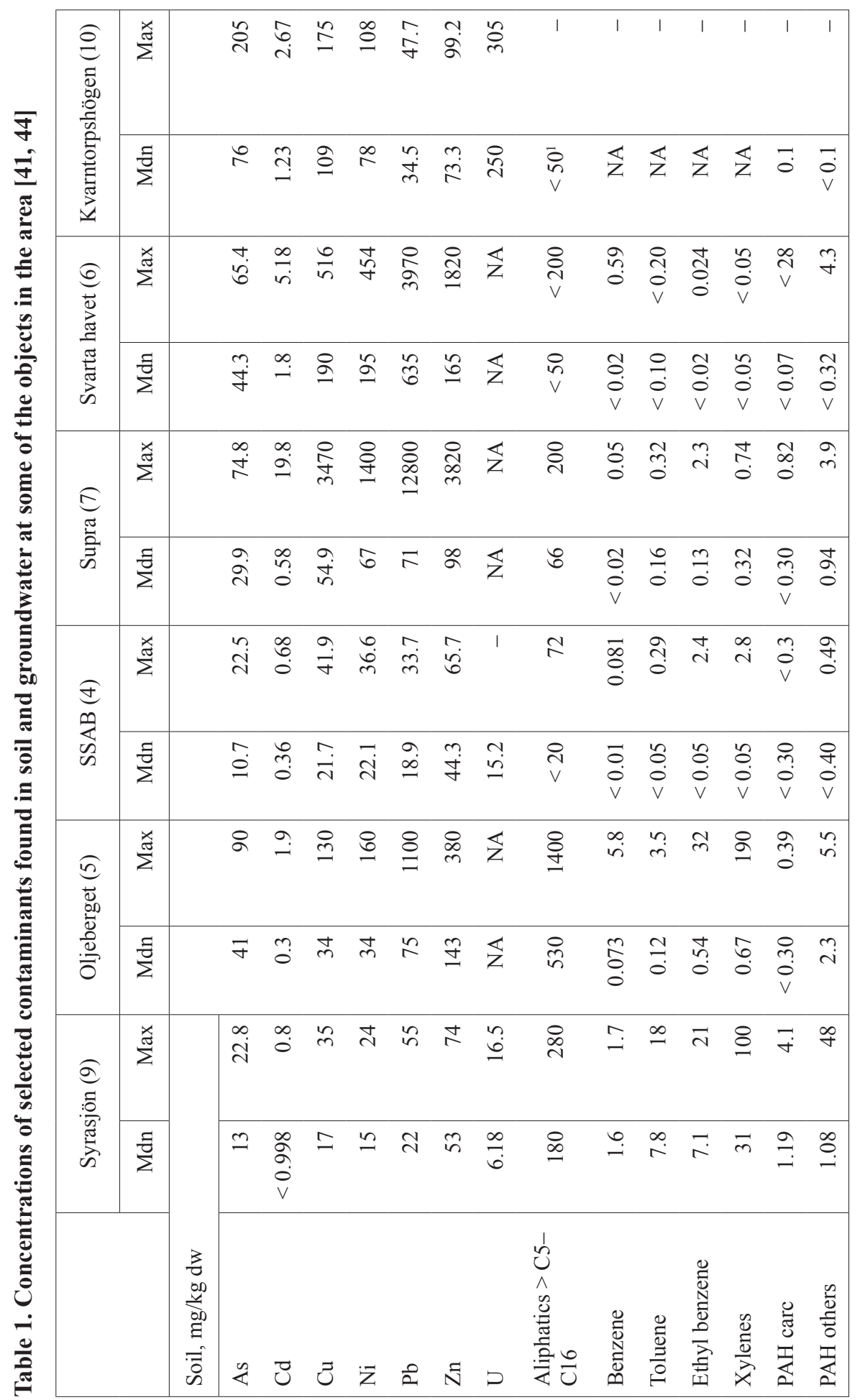




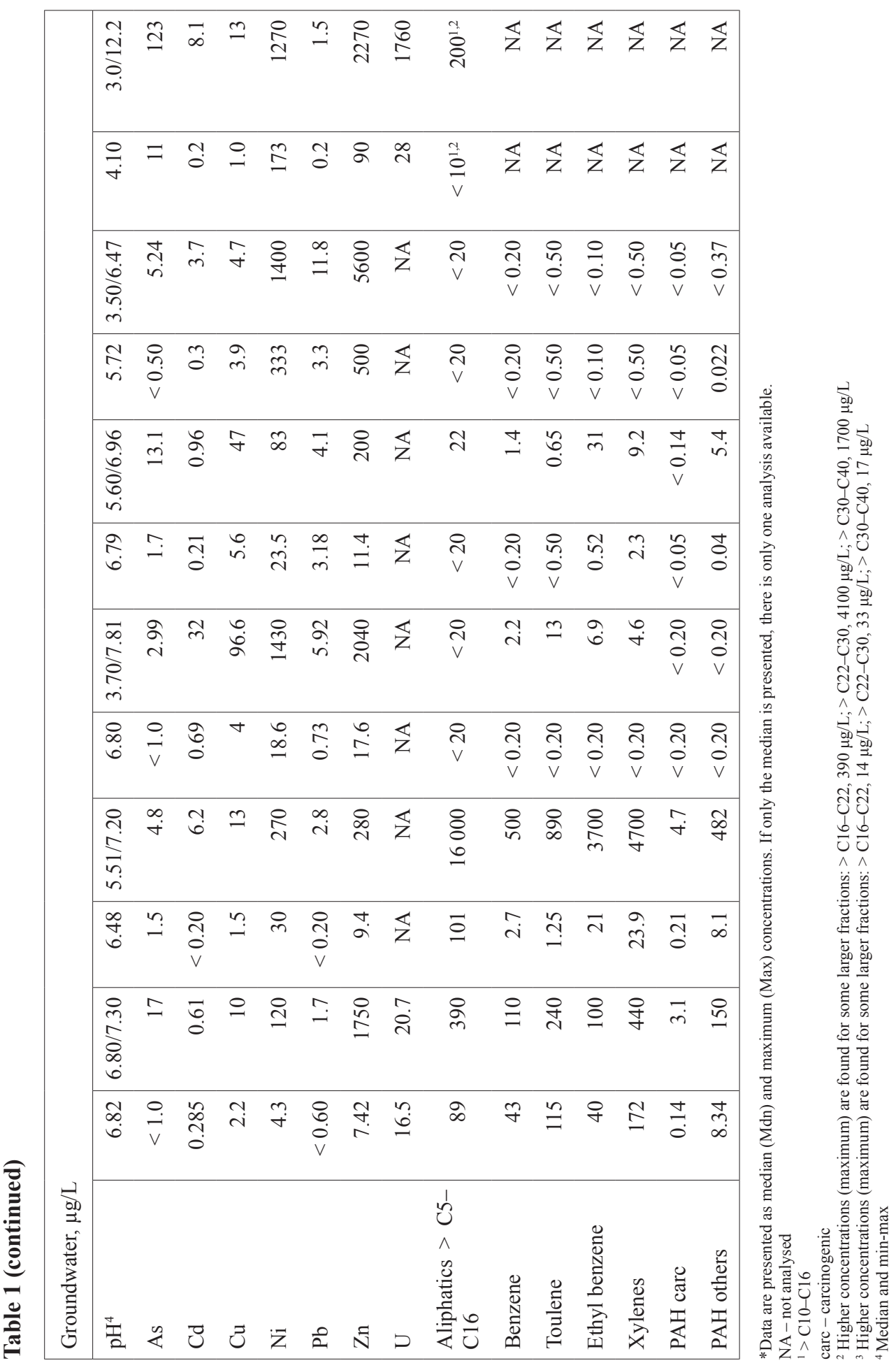


Uranium concentrations up to $5300 \mu \mathrm{g} / \mathrm{L}$ have been found in the groundwater at the leachate pond that received uranium extraction waste [44]. Uranium concentrations in the groundwater are high despite concentrations between $165-188 \mathrm{mg} / \mathrm{kg}$ dw only in the solid phase and a $\mathrm{pH}$ of 7.8 . High calcium concentrations in the groundwater also indicate that the extraction waste was neutralized using limestone prior to release into the pond.

\subsection{Kvarntorpshögen - the waste deposit}

The $\mathrm{pH}$ in groundwaters around Kvarntorpshögen ranges from 3 to 12.2 (Table 1), indicating both sulfide weathering and influence of burned lime. There are examples of high concentrations of nickel as well as of uranium, suggesting that the alum shale waste leaves a signature in the leachates.

\subsection{Serpentine system}

Water quality at the outlet of the Serpentine system has been monitored since 1996. In 1999 there was an apparent increase in the concentrations of lithium and strontium (Fig. 6) due to decreased dilution after redirection of cooling water from an industrial process that previously had been led to the Serpentine system [47]. It has been estimated that the average annual flow from the Serpentine system is about $0.3 \mathrm{Mm}^{3}$ and the cooling water is about 1.2-1.3 $\mathrm{Mm}^{3} /$ year [25]. In 2005 the Serpentine system was restored since the water infiltrated through the dikes instead of passing through the system, and the ponds were overgrown. During the restoration some 4000 tonnes of sediments containing PAHs, aliphatic compounds and metals were removed [47]. Analyses of sediment samples have shown that the concentrations of $\mathrm{Ni}, \mathrm{U}$ and $\mathrm{V}$ in the sediments in 2019 were decreased (see Table 2) despite using a more aggressive digestion method in 2019 than in 2004. There does, however, not seem to be any corresponding decrease in concentrations in the outlet water after the restoration (Fig. 6).

Estimates based on concentrations and water flow indicate a decreased mass transport of uranium and nickel today compared to the 1970s. In 1977, $1100 \mathrm{~kg}$ nickel and $180 \mathrm{~kg}$ uranium were released into Frommestabäcken from the Serpentine ponds, resulting in a total transport to the stream of $1450 \mathrm{~kg}$ nickel and $185 \mathrm{~kg}$ uranium (including water from the western stream and pit lakes) [48]. For 2015-2018 it was estimated that the total annual release of nickel into Frommestabäcken (from the Serpentine system and the western stream and pit lakes) was between 43 and $207 \mathrm{~kg} /$ year and that of uranium, 54-128 kg/year [25]. This indicates a reduction in mass transport from the Serpentine ponds to Frommestabäcken corresponding to $86-97 \%$ for nickel and $31-71 \%$ for uranium. This suggests an important decrease in metal release from the Serpentine system, since it alone was estimated to release $1100 \mathrm{~kg}$ nickel annually in 1970 while the total release to the downstream water is less than a fifth of that today. 


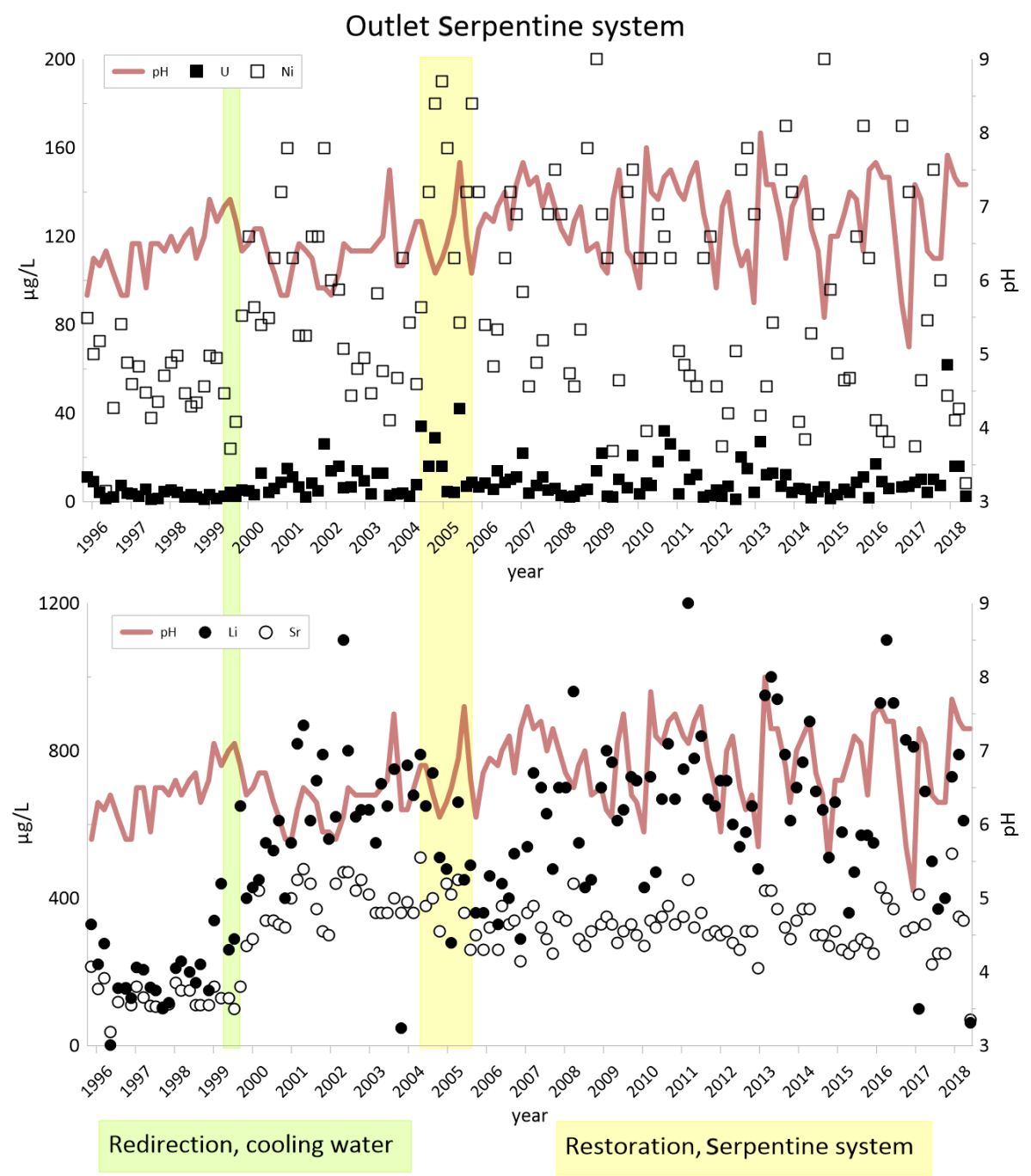

Fig. 6. Diagrams (based on data from [25]) with $\mathrm{pH}$ and concentrations of $\mathrm{U}, \mathrm{Ni}$, $\mathrm{Li}$ and $\mathrm{Sr}$ at the outlet of the Serpentine system, 1996-2018 (average U 1996-1999 $3.7 \mu \mathrm{g} / \mathrm{L}, 2000-200510.8 \mu \mathrm{g} / \mathrm{L}, 2006-20189.66 \mu \mathrm{g} / \mathrm{L}$; average Ni 1996-1999 $53 \mu \mathrm{g} / \mathrm{L}, 2000-2005100 \mu \mathrm{g} / \mathrm{L}, 2006-201893.5 \mu \mathrm{g} / \mathrm{L}$; average $\mathrm{Li} 1996-1999$ $224 \mu \mathrm{g} / \mathrm{L}, 2000-2005609 \mu \mathrm{g} / \mathrm{L}, 2006-2018637 \mu \mathrm{g} / \mathrm{L}$; average $\mathrm{Sr}$ 1996-1999 $132 \mu \mathrm{g} / \mathrm{L}, 2000-2005384 \mu \mathrm{g} / \mathrm{L}, 2006-2018319 \mu \mathrm{g} / \mathrm{L})$.

The decrease in element concentrations from the Serpentine system is also reflected in the decrease in trace element concentrations in the sediments after the restoration compared to those in the sediments accumulated in the ponds between the late 1940s and 2004 (Table 2). For nickel, sediments in the ponds 
showed a maximum of $671 \mathrm{mg} / \mathrm{kg}$ dw in 2004 compared to $23 \mathrm{mg} / \mathrm{kg} \mathrm{dw}$ in 2019. The concentration of uranium, which in 2004 was $271 \mathrm{mg} / \mathrm{kg} \mathrm{dw}$, reached a maximum of $48 \mathrm{mg} / \mathrm{kg} \mathrm{dw}$ in 2019. For several elements, the trace element concentrations in the surficial sediments in 2019 were much lower than prior to the restoration. Maximum concentrations in the upper part of the profiles were $62-93 \%$ lower for arsenic, 74-90\% for molybdenum, 66-97\% for nickel, $56-82 \%$ for uranium and $71-91 \%$ for vanadium in the lake and the pond.

Table 2. Concentrations of $\mathrm{As}, \mathrm{Fe}, \mathrm{Mo}, \mathrm{Ni}, \mathrm{U}$ and $\mathrm{V}$ in sediments from the Serpentine lake and the Serpentine pond in 2004 and 2019, $\mathrm{mg} / \mathrm{kg} \mathrm{dw}$

\begin{tabular}{|l|c|c|c|c|}
\hline & \multicolumn{2}{|c|}{ Lake } & \multicolumn{2}{c|}{ Pond } \\
\hline Element, year & $<15 \mathrm{~cm}^{1}$ & $>15 \mathrm{~cm}^{1}$ & $<15 \mathrm{~cm}^{1}$ & $>15 \mathrm{~cm}^{1}$ \\
As, 2004 & $8.31-764$ & $5.71-321$ & $64.6-203$ & $0.26-171$ \\
As, 2019 & $3.6-292$ & $3.4-86.3$ & $12.2-15.1$ & NA \\
Fe, 2004 & $23600-320000$ & $13200-66900$ & $45700-125000$ & $25200-113000$ \\
Fe, 2019 & $13800-221000$ & $9440-120000$ & $21300-28600$ & NA \\
Mo, 2004 & $1050-3260$ & $15.6-1040$ & $192-38$ & 3.08233 \\
Mo, 2019 & $4.92-841$ & $3.5-611$ & $23.6--32.5$ & NA \\
Ni, 2004 & $38.4-1090$ & 31.0229 & $160-671$ & $25.2-381$ \\
Ni, 2019 & $18.2-376$ & $8.7-199$ & $19.6-23.0$ & NA \\
U, 2004 & $229-618$ & $282-290$ & $178-271$ & $5.95-402$ \\
U, 2019 & $88.9-273$ & $59.8-201$ & $13.5-48.0$ & NA \\
V 2004 & $101-2290$ & $79.2-591$ & $260-811$ & $76.4-331$ \\
V, 2019 & $39-660$ & $23.0-184$ & $55.0-75.0$ & NA \\
\hline
\end{tabular}

${ }^{1}$ Sediment depth

NA - not analysed

In 2019 , no sediment deeper than $15 \mathrm{~cm}$ was retrieved from the pond.

The decreasing concentrations of elements in the outlet from the Serpentine systems as well as in the top layers of the sediments in both the lake and the pond indicate that there is no increased element immobilization in the system but rather a lower input of trace elements into it over the years. 


\subsection{Pit lakes and water courses}

There are four major and several smaller pit lakes in the area. These pit lakes display different water chemistry - both temporal and spatial. Söderhavet and Nordsjön, to the west, have a residence time of about 1.5 years and circumneutral $\mathrm{pH}$. According to reports from 1970 these pit lakes were acidic at that time [49] but seem to have stable buffering capacities now. To the east, Surpölen and Norrtorpssjön have a water residence time of about 20 years. Surpölen is acidic ( $\mathrm{pH}$ about 3.3) and Norrtorpssjön has been circumneutral since around 2000 due to alkaline waste dumping in an adjacent pit. It seems, though, as alkalinity might be decreasing again [50]. One possible reason for the difference in buffering capacity between the lake systems is the higher water residence time for the eastern lakes. Other parameters might be the extent to which the lakes are in contact with the limestone layer (which is not present at all at the location for Surpölen) and alkaline waste impact also in the western system. Sulfate concentrations, however, indicate ongoing weathering in both lake systems. Water filling of the pit lakes has decreased the weathering rates due to lower oxygen availability.

The differences in water quality between upstream and downstream the Kvarntorp area (see Fig. 1b for sampling points) indicates the leaching of alum shale and alum shale waste. The increased concentrations of nickel and uranium are evident in both the western system when water has passed the waste deposit and the eastern system when water has passed the outlet from the eastern lake systems. Except for a few occasions, the concentration of nickel seems to decrease with time downstream west, a trend not seen for uranium. This suggests a decreased leaching of nickel from the waste deposit, which agrees with the mass transport reduction from the Serpentine ponds which was greater for nickel than for uranium. This behavior is probably due to the fact that uranium is more easily leached using carbonate solutions [51], while nickel is being immobilized to a higher degree at the current $\mathrm{pH}$.

Table 3 shows that also the concentrations of $\mathrm{Ca}, \mathrm{K}, \mathrm{Mg}$, Li and $\mathrm{Sr}$ increase through the area in both the western and eastern system. Comparing the concentrations from the Serpentine system $\mathrm{Li}, \mathrm{Ni}$ and $\mathrm{Sr}$ are clearly added to the surface water system from the waste deposit.

Even though alum shale is enriched in vanadium and the waste contains arsenic, the concentrations of these elements are lower downstream than upstream (Table 3), which is most likely due to co-precipitation with iron minerals. Figure 7 shows a Piper diagram where downstream water in both the western and eastern water courses indicate an influence of sulfate rich mine drainage, whereas upstream samples indicate calcium bicarbonate waters. This suggests the consumption of carbonates by weathering sulfides as water passes the mined alum shale area. 


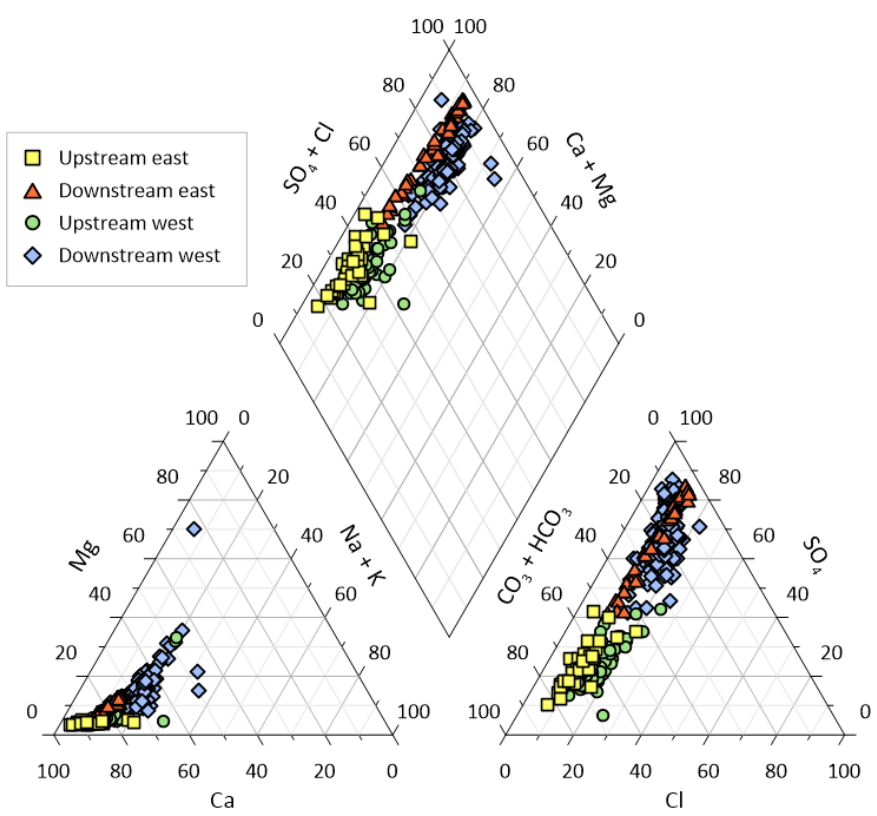

Fig. 7. Piper diagram based on data from [25]. Upstream west is represented by $1997-$ 1998 and 2004-2014, downstream west by 1993-2018, downstream and upstream east by 2012-2018.

Table 3. Median, minimum and maximum concentrations of $\mathrm{Ca}, \mathrm{Fe}, \mathrm{K}, \mathrm{Mg}, \mathrm{As}$, Li, Mo, Ni, Sr, U and V in surface water (data from [25])

\begin{tabular}{|l|l|l|l|l|l|}
\hline & Upstream & Outlet & Downstream & Upstream East & Downstream \\
West & Serpentine & West & $\mathrm{n}=40$ \\
$\mathrm{n}=69$ & $(2012-2018)$ & $\mathrm{n}=42$ \\
& $(1997-2014)$ & $(1996-2018)$ & $(1993-2018)$ & & $(2012-2018)$ \\
\hline $\mathrm{pH}$ & 7.8 & 6.6 & 7.7 & 8 & 7.7 \\
& $7.2-8.3$ & $5.1-8$ & $6.4-9.7$ & $7.6-8.3$ & $7.3-8.2$ \\
$\mathrm{Ca}$, & 41 & NA & 130 & 83 & 180 \\
$\mathrm{mg} / \mathrm{L}$ & $19-77$ & & $38-220$ & $62-200$ & $83-520$ \\
$\mathrm{Fe}$, & 0.66 & 0.52 & 0.65 & 0.31 & 0.42 \\
$\mathrm{mg} / \mathrm{L}$ & $0.015-4.1$ & $0.032-64$ & $0.03-6$ & $0.034-1.4$ & $0.13-1.6$ \\
$\mathrm{~K}$, & 2 & $\mathrm{NA}$ & 22 & 2.3 & 11.5 \\
$\mathrm{mg} / \mathrm{L}$ & $1-19$ & & $9.3-94$ & $1.5-12$ & $3.1-33$ \\
$\mathrm{Mg}$, & 1.62 & $\mathrm{NA}$ & 17 & 2.4 & 16 \\
$\mathrm{mg} / \mathrm{L}$ & $0.85-14$ & & $5.5-246$ & $1.7-4.8$ & $4-50$ \\
$\mathrm{As}$, & 1.2 & 0.3 & 0.6 & 0.76 & 0.63 \\
$\mu \mathrm{g} / \mathrm{L}$ & $0.4-2.4$ & $0.025-3.5$ & $0.1-3$ & $0.3-10$ & $0.31-1.6$ \\
$\mathrm{Li}$, & $>50$ & 600 & 80 & $>50$ & 71 \\
$\mu \mathrm{g} / \mathrm{L}$ & & $2-1200$ & $25-420$ & & $25-220$ \\
\hline
\end{tabular}


Table 3 (continued)

\begin{tabular}{|l|l|l|l|l|l|}
\hline $\mathrm{Mo}$, & 2.7 & 3 & 11 & 3.4 & 4.4 \\
$\mu \mathrm{g} / \mathrm{L}$ & $1.2-8.3$ & $0.5-33$ & $1.6-78$ & $2.2-23$ & $2.7-8.9$ \\
$\mathrm{Ni}$, & 1.45 & 78 & 16 & 1.2 & 4.45 \\
$\mu \mathrm{g} / \mathrm{L}$ & $0.4-3.1$ & $4.8-200$ & $3.9-97$ & $0.1-3$ & $1.4-13$ \\
$\mathrm{Sr}$, & 52.5 & 320 & 250 & 91 & 625 \\
$\mu \mathrm{g} / \mathrm{L}$ & $22-140$ & $38-520$ & $60-510$ & $47-230$ & $160-2100$ \\
$\mathrm{U}$, & 5.1 & 6.1 & 17 & 9.2 & 16.5 \\
$\mu \mathrm{g} / \mathrm{L}$ & $2.4-21$ & $1-62$ & $2.7-28$ & $4.3-27$ & $9.4-34$ \\
$\mathrm{~V}$, & 1.2 & 0.46 & 0.47 & 0.61 & 0.525 \\
$\mu \mathrm{g} / \mathrm{L}$ & $0.4-4.5$ & $0.025-10$ & $0.07-20.6$ & $0.23-2.7$ & $0.12-0.89$ \\
\hline
\end{tabular}

$\mathrm{n}$ - number of samples

Years of sampling are given in parentheses

NA - not analysed

\section{Conclusions}

Industrial activities have profoundly affected the Kvarntorp area - both by reshaping the landscape and by releasing pollutants into the air and the aquatic environment. Using a combination of archive studies, environmental monitoring and additional sampling provides a thorough understanding of the environmental problems as well as of the effects changed with time.

There is a long-term impact from the industrial shale oil production. For hydrocarbons the current contamination is mainly local and no major leaching is occurring as indicated by low concentrations in surface waters. Hydrocarbons are mainly found in soil and groundwater in subareas used for storage or destruction of organic waste materials (Syrasjön, Oljeberget, Supra). Elevated trace element concentrations are mainly found in subareas for waste (Supra, Svarta havet, Kvarntorpshögen) with higher concentrations in groundwater due to lower $\mathrm{pH}$. Differences in trace element concentrations upstream and downstream the area also reveal an ongoing weathering of exposed alum shale and shale residues. Transport of trace elements and sulfate from the area is thus still significant but has probably decreased throughout the years as indicated by archive data. Most of the pit lakes have circumneutral $\mathrm{pH}$ but historical records tell about low $\mathrm{pH}$ during the 1970s. Only one of the pit lakes still has a $\mathrm{pH}$ of about 3.3 but all of them have elevated sulfate concentrations indicating still ongoing weathering. Annual transport of nickel and uranium from the waste deposit area seems to have decreased since the 1970s, but it is difficult to make exact comparisons due to sparse archive data from earlier years. There are strong indications, though, that there has been a decrease in nickel leaching from the deposit area and a reduction in mass transport in Frommestabäcken from $1450 \mathrm{~kg}$ annually in the 1970s to less than $210 \mathrm{~kg}$ annually. Uranium leaching has also decreased, but to a much lesser extent, from $185 \mathrm{~kg}$ annually to less than $130 \mathrm{~kg}$. 
Archive material has shown that at the beginning of the oil production, focus was not on environmental issues. This means that measures were not primarily taken to protect the environment and that records about waste and environmental impact are scarce. Documentation about clearly noticeable problems such as damaged vegetation or bad smelling water is available, though, due to the fact that there were complaints from neighbours affected. Even fragmentary historical information is valuable and it is known that during the oil production years there was a significant release of sulfur dioxide and flue gas particles into the air, but also a significant release of organic as well as inorganic components into the surface waters. So far, information about, for example, trace element concentrations in downstream water from the production time has not been found. The release of trace elements into the environment did not pose a visible problem for the company as its main concern was production, not environmental issues.

In many aspects the area has recovered from the oil production era. Vegetation has returned, the downstream water does not smell badly and on top of the waste deposit visitors are offered a view of the landscape. This differs from the production time when the environmental impact was severe both locally and regionally, even though still today, sulfide weathering with metal release is a remaining consequence of the past activities.

A summarizing conclusion is that during the production, the release of organic contaminants was more obvious than that of elements. Much of the released contaminants have been contained within the industrial area and the Serpentine systems. Release of pollutants still continues today, with organic contaminants impacting locally and trace elements, on a local and regional level.

Several topics, such as the cooling rate of the waste deposit and future leaching conditions, merit further investigations.

\section{Acknowledgements}

Kumla municipality is gratefully acknowledged for access to data from the water monitoring programme as well as for permission to sample in the area. ArkivCentrum, Örebro is gratefully acknowledged for providing access to historical documents.

\section{REFERENCES}

1. Brittingham, M. C., Maloney, K. O., Farag, A. M., Harper, D. D., Bowen, Z. H. Ecological risks of shale oil and gas development to wildlife, aquatic resources and their habitats. Environ. Sci. Technol., 2014, 48(19), 11034-11047.

2. Fu, X., Wang, J., Zeng, Y., Tan, F., Feng, X. Trace elements and their behaviour during the combustion of marine oil shale from Changliang Mountain, northern 
Tibet, China. Environ. Earth Sci., 2013, 70, 1125-1134.

3. Lenhard, L. G., Andersen, S. M., Coimbra-Araújo, C. H. Energy-environmental implications of shale gas exploration in Paraná Hydrological Basin, Brazil. Renew. Sustain. Energy Rev., 2018, 90, 56-69.

4. Nduagu, E. I., Gates, I. D. Unconventional heavy oil growth and global greenhouse gas emissions. Environ. Sci. Technol., 2015, 49(14), 8824-8832.

5. Slonecker, E. T., Milheim, L. E. Landscape disturbance from unconventional and conventional oil and gas development in the Marcellus shale region of Pennsylvania, USA. Environments, 2015, 2(2), 200-220.

6. Toomik, A., Liblik, V. Oil shale mining and processing impact on landscapes in north-east Estonia. Landsc. Urban Plan., 1998, 41(3-4), 285-292.

7. Väizene, V., Valgma, I., Karu, V., Orru, M. Environmental impact of oil shale mining. Environ. Earth Sci., 2016, 75, 1201.

8. Vallner, L., Gavrilova, O., Vilu, R. Environmental risks and problems of the optimal management of an oil shale semi-coke and ash landfill in Kohtla-Järve, Estonia. Sci. Total Environ., 2015, 524-525, 400-415.

9. Jefimova, J., Irha, N., Reinik, J., Kirso, U., Steinnes, E. Leaching of polycyclic aromatic hydrocarbons from oil shale processing waste deposit: A long-term field study. Sci. Total Environ., 2014, 481, 605-610.

10. Bhargava, S. K., Ram, R., Pownceby, M., Grocott, S., Ring, B., Tardio, J., Jones, L. A review of acid leaching of uraninite. Hydrometallurgy, 2015, 151, $10-24$.

11. Baigenzhenov, O., Khabiyev, A., Mishra, B., Turan, M. D., Akbarov, M., Chepushtanova, T. Uranium (VI) recovery from black shale leaching solutions using ion exchange: Kinetics and equilibrium studies. Minerals, 2020, 10(8), 689.

12. Lavergren, U., Åström, M. E., Falk, H., Bergbäck, B. Metal dispersion in groundwater in an area with natural and processed black shale - Nationwide perspective and comparison with acid sulfate soils. Appl. Geochem., 2009, 24(3), 359-369.

13. Puura, E. Weathering of Mining Waste Rock Containing Alum Shale and Limestone: A Case-Study of the Maardu Dumps, Estonia. PhD thesis. Department of Chemical Engineering and Technology, KTH Royal Institute of Technology, Stockholm, 1998.

14. Andersson, A., Dahlman, B., Gee, D. G., Snäll, S. The Scandinavian Alum Shales. Geological Survey of Sweden, 1985, Ser. Ca, No. 56, Uppsala, 1-50.

15. Bruton, D. L., Gabrielsen, R. H., Larsen, B. T. The Caledonides of the Oslo Region, Norway - stratigraphy and structural elements. Nor. J. Geol., 2010, 90, 93-121.

16. Pabst, T., Sørmo, E., Endre, E. Geochemical characterisation of Norwegian Cambro-Ordovician black mudrocks for building and construction use. Bull. Eng. Geol. Environ., 2017, 76, 1577-1592.

17. Wilke, F. D. H., Schettler, G., Vieth-Hillebrand, A., Kühn, M. Activity concentrations of ${ }^{238} \mathrm{U}$ and ${ }^{226} \mathrm{Ra}$ in two European black shales and their experimentally-derived leachates. J. Environ. Radioact., 2018, 190-191, $122-129$. 
18. Jüriado, K., Raukas, A., Petersell, V. Alum shales causing radon risks on the example of Maardu area, North-Estonia. Oil Shale, 2012, 29(1), 76-84.

19. Eklund, M., Bergbäck, B., Lohm, U. Reconstruction of historical cadmium and lead emissions from a Swedish alumworks, 1726-1840. Sci. Total Environ., 1995, 170(1-2), 21-30.

20. Falk, H., Lavergren, U., Bergbäck, B. Metal mobility in alum shale from Öland, Sweden. J. Geochem. Explor., 2006, 90(3), 157-165.

21. Bäckström, M., Börjesson, E., Karlsson, S. Diurnal variations of abiotic parameters in a stream, recipient for drainage water in Ranstad, southwest Sweden. J. Environ. Monit., 2002, 4, 772-777.

22. Kalinowski, B. E., Johnsson, A., Arlinger, J., Pedersen, K., Ödegaard-Jensen, A., Edberg, F. Microbial mobilization of uranium from shale mine waste. Geomicrobiol. J. 2006, 23(3-4), 157-164.

23. Bengtson, P. Hydrogeology of the Kvarntorp Area. Geological Survey of Sweden, 1971, SER C, No 667, Yearbook 65, No 13 (in Swedish, English abstract and summary).

24. Hessland, I., Armands, G. Alum shale - geology. Statens industriverk: SIND PM, 1978, 3, Stockholm (in Swedish).

25. Kumla Municipality. Water Monitoring Program in Kvarntorp, 1993-2018 (one report every year, in Swedish).

26. Schwartz, S. The shale oil plant at Kvarntorp. Offprint from Näringsliv och Kultur, 1945, 23 pp. (in Swedish).

27. SOU (Swedish Government Official Reports), 1961, 27, Stockholm, 144 pp. (in Swedish).

28. Kumla Municipality Digital Photo Archive. https://kk.kulturhotell.se/ (accessed December $\left.4^{\text {th }} 2019\right)$.

29. Werner, D. Expansion of the shale oil industry during the last year. Teknisk Tidskrift, 1942, 72, booklet 37, 417-424 (in Swedish).

30. Zeidler, W. Overview of our shale supply. Skifferskriften, 1953, 4, 9-15 (in Swedish).

31. Schjånberg, E. News from the research department. Skifferskriften, 1955, 6, 8-10 (in Swedish).

32. Brandberg, A. The fines issue. Skifferskriften, 1956, 1, 11-13 (in Swedish).

33. Sundqvist, S. The Ljungström plant. Skifferskriften, 1956, 2, 8-10 (in Swedish).

34. SSAB. Technical Economical Analysis. 1956, nr 4, del 1 (archive material in Swedish).

35. Liebgott, N. Account of the Drilling Procedure in the Case of Oil Shale Mining in Närke, Kvarntorp, January 8th 1963 (archive material in Swedish).

36. SSAB. Account of the Operations at the Kvarntorp Plant-Main Department T-During the Financial Year 1959/60 and an Overview of the Period 1952/531959/60 (archive material in Swedish).

37. Hjalmarsson, H., Pilo, C. W. Administration report for the business year 1962-1963. Skifferskriften, 1963, 2, 5-12 (in Swedish).

38. Hjalmarsson, H., Pilo, C. W. Administration report for the business year 
1963-1964. Skifferskriften, 1964, 1, 4-8 (in Swedish).

39. Skye, E. The influence of air pollution on the fruticulous and foliaceous lichen flora around the shale oil works at Kvarntorp in the province of Närke. Svensk Botanisk Tidskrift, 1958, 52, 133-190 (in Swedish, with summary in English).

40. Growth, B., Åkerlind, G. Österbygden Water Court. Account for 74/1944, Development and Affected Water Bodies, 1955 (archive material in Swedish).

41. Holm, T., Ekholm, D., Johansson, L., Bäckström, M., Rehn, I., Forsmark, T., Axenhamn, L., Sundblad, B. Kvarntorp Area - Study of the Waste Deposit. SWECO VIAK AB and Geological Survey of Sweden, 2005 (report in Swedish).

42. Wikström, S. Kvarntorp Waste Deposit, Investigation Report. Kumla brandförsvar, 1983 (report in Swedish).

43. Tydén, Å. Contractual relationship between SSAB and SSV. Skifferskriften, 1961, 4, 12-13 (in Swedish).

44. Ekholm, D., Bäckström, M., Johansson, L., Holm, T., Heinemo, S-Å. The Kvarntorp Area. Investigation Regarding Soil Pollution - Pilot Study. Geological Survey of Sweden, 2005, project number 43033, 108 pp. (report in Swedish).

45. SOU (Swedish Government Official Reports), 1956, 58, part 2, 82-114 (in Swedish).

46. Johansson, S., Orrenius, J. Letter to Swedish Government 1976-03-19, from Svenska Skifferaktiebolaget (SSAB) and Luossavaara-Kiirunavaara Aktiebolag (LKAB), 10 pages (archive material in Swedish).

47. SWECO VIAK. Serpentine Pond System in Kvarntorp - Summarising Report Regarding Restoration Measures in the Serpentine System, Kvarntorp, 20032005, 2005 (report in Swedish).

48. Kumla Municipality and Örebro County Administrative Board. The Environment in Kvarntorp, 1979 (in Swedish).

49. Salomonsson, G. Diversion of Ammonia Water to the Kvarntorp Lakes Investigation for Swedish Saltpeter Works. Terra Bona, 1970 (report in Swedish).

50. Åhlgren, K., Sjöberg, V., Grawunder, A., Allard, B., Bäckström, M. Chemistry of acidic and neutralized alum shale pit lakes 50 years after mine closure, Kvarntorp, Sweden. Mine Water Environ., 2020, 39, 481-497.

51. Francis, C. W., Timpson, M. E., Wilson, J. H. Bench- and pilot-scale studies relating to the removal of uranium from uranium-contaminated soils using carbonate and citrate lixiviants. J. Hazard. Mater., 1999, 66(1-2), 67-87. 